\title{
MJN NUTRITIONAL STATUS AMONG ELDERLY RESIDING IN LONGHOUSES AT KUCHING, SARAWAK
}

\author{
Tan Jia Hui, Chang Woan Ching* \\ International Medical University, Kuala Lumpur, Malaysia \\ *Corresponding Author's Email: changwoanching@imu.edu.my
}

\begin{abstract}
Background: Nutrition is a major aspect in healthcare. Poor nutritional status may affect elderly particularly during the aging process. It becomes the challenge for older population to maintain their health with good nutritional level. Objectives: This study aims to investigate the nutritional status among elderly in longhouses and its' association with demographic factors. Methods: This is a cross-sectional quantitative study. A total of 109 Malaysian older adults were recruited using convenience sampling method. The MNA®SF questionnaire was adopted to determine the nutritional status among elderly. Results: The findings of the study show that elderly at longhouses are at risk for malnutrition $(\mathrm{M}=10.15, \mathrm{SD}=2.289)$. There is a statistically significant relationship between age/alcohol consumption and nutritional status $(p<0.05)$. Conclusion: The study reveals an important information regarding nutrition status of the elderly residing in long houses at Kuching and Serian divisions. The local public health providers are recommended to take further actions in enhancing the nutritional status of the older population in Sarawak.
\end{abstract}

Keywords: Nutritional Status; Elderly; Longhouses

\section{INTRODUCTION}

Malnutrition is a major concern and it is always being neglected by the community. Physiological changes due to aging may affects the nutritional needs and intake of the elderly and that leading to malnutrition (Churak et al., 2019). Other factors causing inadequate nutrition intake include problems in cognitive ability, socioeconomic status, food accessibility and environmental factors (Patil $\&$ Shindhe, 2018). Malnutrition can also cause negative implications such as weight loss, poorer health outcomes and increased risk of morbidity and mortality.

Maintaining a good nutritional status is essential for elderlies to maximise their physical and cognitive performances, overall health, and quality of life. However, the prevalence of malnutrition among elderly is on the rise (Amarya, Singh \& Sabharwal, 2015). Many elderlies have low food intake and/or consume poor quality diet that result in lower nutritional status and weight loss over a long period of time (Mangels, 2018; Poda et al., 2019). Gomes, Soares \& Gonçalves
(2016) and Nohan et al., (2020) reported that age, gender, level of education, socioeconomic status, mouth or teeth problems and having less than four meals a day are those factors that affecting quality of dietary intake among elderly. In their studies, Lin et al., (2017) and Churak et al., (2019) revealed that age $(p=0.002)$ was correlated significantly with nutritional status in which older age was associated with poor nutrition level among older adults. The findings of the studies are congruent with Wong et al., (2019) that elderly aged from 60 and above are at risk of malnutrition.

Lifestyle factors such as smoking, and alcohol consumption are found to be associated with increased risk of malnutrition among elderly. According to Zainal et al., (2019) individual who smoke more than 20 cigarettes per day has poorer dietary practice and diet quality compared to those who never smoked. In addition, Lin et al., (2017) reported that smoking has direct effect on lower level of nutrition $(p=0.055)$ on elderly related to tobacco effect asiciated with poorer 
taste sensation and lower appetite. Similarly, Churak et al., (2019) found smoking is associated with the elderly's nutritional status $(p<0.001)$. The findings from the literature suggest that prolonged addiction to tobacco would increase the risk of malnutrition among elderly. In their study, Lin et al. (2017) also reported that alcohol consumption causes increased risk of poor nutrition among elderly $(p<0.001)$. Both smoking and alcohol consumption increase the risk for many health consequences and malnutrition among the elderly population.

Other factors that may affect nutritional status include low education level, single/widow status, and low income in older adults (Poda et al., 2019). At the study sites, majority of the elderly are retired and many of them are on low income from farming. Older people with economic disadvantage and/or lower educational level have lack of knowledge on nutrition information and food choices, and that leading to poor dietary patterns (Cheong et al., 2017). These findings are supported by Shahar et al. 2019 that low socioeconomic status is associated with poor nutritional status among the older population. Besides, psychosocial vulnerability is also linked to high risk of mortality in elderly. Many of the elderly from rural areas are either living alone or with their old spouse while children are away in urban areas for work commitment or extended family (Agree, 2018). Past literature shows that older adults who are socially isolated are also at a greater risk of dietary inadequacy. Apparently, it is due to poor social support in practicing good diet habit (Rapacciuolo et al., 2019).

Nutritional assessment for older population is important particularly for those in the rural areas. Elderly residents in the Sarawak districts are experiencing difficulties for adequate healthcare services due to poor transportation access (Azhar et al., 2016). In addition, most of the residents are depending on the social welfare support and financial assistance from their children. These prompt the researchers to investigate the nutritional status of the elderly population residing in longhouses, Sarawak. The findings of the study will be useful for the public health division in the respective areas to further strategies health-related programmes for the targeted population.

\section{Purpose of the Study}

The purpose of the study was to determine the nutritional status among elderly and its' association with demographic factors among elderly residing at long houses in Serian and Kuching divisions, Sarawak.

\section{Research Questions}

1. To determine the nutritional status among the elderly residing at long houses at Kuching.

2. To determine the association between nutritional status and demographic factors (age, gender, smoking, alcohol consumption) among elderly residing at long houses at Kuching.

\section{METHODOLOGY}

A cross-sectional descriptive quantitative study was used to determine the nutritional status among elderly residing in long houses in Kuching. The study was conducted at Kuching division (Kampung Bumbok, Seratau and Punau) and Serian division (Kampung Pichin and Taee). A total of 109 elderly participated in the study.

Mini Nutritional Assessment Short Form (MNA ${ }^{\circledR}$ SF) was adopted from Nestle Nutrition Institution with permission to assess the nutritional status of elderly. The MNA ${ }^{\circledR}-S F$ consists of 6 items on screening of food intake, weight loss, mobility, psychological, neuropsychological condition, and calf circumference The scoring system of the tool is categorised into: 0-7 points (malnourished), 8-11 points (at risk of malnutrition) and 12-14 points (normal nutrition status).

A panel of three experts include two Pegawai Sains Pemakanan Gred U41 and one lecturer from Nutrition \& Dietician division validated the questionnaire. Thirty participants were employed for the pilot study. The Intra Class Correlation Coefficient (ICC) value 0.89 was obtained, indicating an excellent reliability of the MNA ${ }^{\circledR}-S F$ tool for the study. Thus, no amendment was done to the questionnaire.

\section{DataAnalysis}

Data was analysed using the Statistical Packages for the Social Sciences (SPSS) version 26. Normality of the data is assumed in this study. Therefore, the association between the demographic factors and nutritional status was done using Pearson correlation test (age) and independent $t$-test (gender, smoking, alcohol consumption).

\section{RESULTSAND DISCUSSION}

Table 1 shows the demographic data of the elderly 
participants. Majority of the elderly participants were aged between age 60 to 69 years, and with mean age of $72.6(\mathrm{SD}=7.761)$. More than half of the participants were females $(58.1 \%)$ and the rest were $41.4 \%$ males. With regards to race, majority participants were Bidayuh (97.2\%). For marital status, $93.6 \%$ of the participants are married and $6.4 \%$ are single. Most of the them $(44 \%)$ did not have a formal education. Of this, their highest education level was at the primary level $(41 \%)$, and only $12.8 \%$ participants were at secondary level and above. Approximately $77.1 \%$ of the participants were unemployed. The mean household income was at RM $349.17 \pm$ SD 383.056. Majority of them (94.5\%) earn less than RM 1200 per month. This is in line with the mean household income reported under the Program Pembasmian Kemiskinan Bandar (PPKB) 2019 by Ministry of Health in Malaysia (Ministry of Health, 2019).

The BMI was at a mean value of 23.32 $(\mathrm{SD}=4.8707)$. Data reported that $52.4 \%$ participants were overweight and obese, $38.5 \%$ had a normal weight, and $10.1 \%$ was underweight. More than half of the elderly $(59.6 \%)$ have a calf circumference of 31 centimeters and above $(\mathrm{M}=32.4 \pm \mathrm{SD} 3.881)$. In relation to medical conditions, $35.8 \%$ elderly has gastrointestinal disease, less than $5 \%$ for cardiovascular disease and cancer and none reported for liver disease based on their medical record. Approximately $23 \%$ and $79 \%$ elderly participants have medical history of diabetes and hypertension respectively. Many elderlies $(82.6 \%)$ claim they do not smoke, while $31.2 \%$ of them consume alcohol with about 3 glasses per week. More than half $(56.9 \%)$ participants do not wear dentures, and $65.1 \%$ of them indicated they have difficulty in chewing food.

Table 1: Descriptive Analysis on Demographic Data of Participants $(n=109)$

\begin{tabular}{|c|c|c|c|c|}
\hline Variables & $\begin{array}{c}\text { Frequ } \\
\text { ency } \\
\text { (f) }\end{array}$ & $\begin{array}{c}\text { Percentage } \\
(\%)\end{array}$ & $\begin{array}{c}\text { Mean } \\
(\mathrm{M})\end{array}$ & $\begin{array}{c}\text { Standard } \\
\text { Deviation } \\
\text { (SD) }\end{array}$ \\
\hline \multicolumn{3}{|l|}{ Age } & \multirow[t]{4}{*}{72.6} & \multirow[t]{4}{*}{7.761} \\
\hline $60-69$ & 46 & 43.1 & & \\
\hline $70-79$ & 36 & 33 & & \\
\hline $80-89$ & 26 & 23.9 & & \\
\hline \multicolumn{5}{|l|}{ Gender } \\
\hline Male & 45 & 41.3 & & \\
\hline Female & 64 & 58.7 & & \\
\hline
\end{tabular}

\begin{tabular}{|c|c|c|c|c|}
\hline \multicolumn{5}{|l|}{ Race } \\
\hline Bidayuh & 106 & 97.2 & & \\
\hline Others & 3 & 2.8 & & \\
\hline \multicolumn{5}{|l|}{ Marital status } \\
\hline Married & 102 & 93.6 & & \\
\hline Single & 7 & 6.4 & & \\
\hline \multicolumn{5}{|l|}{ Education level } \\
\hline $\begin{array}{l}\text { No formal } \\
\text { education }\end{array}$ & 48 & 44 & & \\
\hline Primary & 45 & 41 & & \\
\hline Secondary & 14 & 12.8 & & \\
\hline Tertiary & 2 & 1.8 & & \\
\hline \multicolumn{5}{|l|}{ Job status } \\
\hline $\begin{array}{l}\text { Employed/self } \\
\text { employed }\end{array}$ & 25 & 22.9 & & \\
\hline Unemployed & 84 & 77.1 & & \\
\hline \multicolumn{3}{|l|}{$\begin{array}{l}\text { Household } \\
\text { income }\end{array}$} & \multirow[t]{4}{*}{$\begin{array}{c}\mathrm{RM} \\
349.17\end{array}$} & \multirow[t]{4}{*}{383.056} \\
\hline $\begin{array}{l}<\mathrm{RM} \\
1200 / \text { month }\end{array}$ & 103 & 94.5 & & \\
\hline $\begin{array}{l}\geq \mathrm{RM} 1200 \text { to } \\
\text { RM1500 }\end{array}$ & 4 & 3.7 & & \\
\hline$>$ RM 1500 & 2 & 1.8 & & \\
\hline \multicolumn{3}{|l|}{ BMI } & \multirow[t]{6}{*}{23.32} & \multirow[t]{6}{*}{4.8707} \\
\hline $\begin{array}{l}\text { Underweight } \\
<18.5\end{array}$ & 11 & 10.1 & & \\
\hline $\begin{array}{l}\text { Normal } \\
\text { weight } 18.5 \text { - } \\
22.9\end{array}$ & 42 & 38.5 & & \\
\hline $\begin{array}{l}\text { Overweight } 23 \\
-24.9\end{array}$ & 22 & 21.2 & & \\
\hline $\begin{array}{l}\text { Obese I } 25 \text { - } \\
29.9\end{array}$ & 27 & 24.8 & & \\
\hline Obese II $\geq 30$ & 7 & 6.4 & & \\
\hline \multicolumn{3}{|l|}{$\begin{array}{l}\text { Calf } \\
\text { circumference } \\
\text { (CC) }\end{array}$} & \multirow[t]{3}{*}{32.4} & \multirow[t]{3}{*}{3.881} \\
\hline $\begin{array}{l}\text { CC less than } \\
31\end{array}$ & 44 & 40.4 & & \\
\hline $\begin{array}{l}\text { CC } 31 \text { and } \\
\text { greater }\end{array}$ & 65 & 59.6 & & \\
\hline \multicolumn{5}{|l|}{$\begin{array}{l}\text { Gastrointestinal } \\
\text { disease }\end{array}$} \\
\hline Yes & 39 & 35.8 & & \\
\hline No & 70 & 64.2 & & \\
\hline \multicolumn{5}{|l|}{ Liver disease } \\
\hline Yes & 0 & 0 & & \\
\hline No & 109 & 100 & & \\
\hline
\end{tabular}




\begin{tabular}{|c|c|c|c|c|}
\hline \multicolumn{5}{|l|}{$\begin{array}{l}\text { Cerebrovascular } \\
\text { disease }\end{array}$} \\
\hline Yes & 5 & 4.6 & & \\
\hline No & 104 & 95.4 & & \\
\hline \multicolumn{5}{|l|}{$\begin{array}{l}\text { Diabetes } \\
\text { Mellitus }\end{array}$} \\
\hline Yes & 25 & 22.9 & & \\
\hline No & 84 & 77.1 & & \\
\hline \multicolumn{5}{|l|}{ Hypertension } \\
\hline Yes & 86 & 78.9 & & \\
\hline No & 23 & 21.1 & & \\
\hline \multicolumn{5}{|l|}{ Cancer } \\
\hline Yes & 2 & 1.8 & & \\
\hline No & 107 & 98.2 & & \\
\hline \multicolumn{5}{|l|}{ Smoking } \\
\hline Yes & 19 & 17.4 & & \\
\hline No & 90 & 82.6 & & \\
\hline $\begin{array}{l}\text { Cigarette } \\
\text { sticks/day }\end{array}$ & 19 & 17.4 & 1.7 & 4.019 \\
\hline $\begin{array}{l}\text { Years of } \\
\text { smoking }\end{array}$ & 19 & 17.4 & 6.8 & 15.68 \\
\hline \multicolumn{5}{|l|}{$\begin{array}{l}\text { Alcohol } \\
\text { consumption }\end{array}$} \\
\hline Yes & 34 & 31.2 & & \\
\hline No & 75 & 68.8 & & \\
\hline \multicolumn{3}{|l|}{$\begin{array}{l}\text { Frequency of } \\
\text { alcohol } \\
\text { consumption } \\
\text { (glass/week) }\end{array}$} & 3.4 & 0.942 \\
\hline $\begin{array}{l}\text { Sometime (1-2 } \\
\text { times/month) }\end{array}$ & 2 & 1.8 & & \\
\hline $\begin{array}{l}\text { Seasonal (1-2 } \\
\text { times/year) }\end{array}$ & 29 & 26.6 & & \\
\hline $\begin{array}{l}\text { Frequently (at } \\
\text { least } \\
\text { once/week) }\end{array}$ & 3 & 2.8 & & \\
\hline \multicolumn{5}{|l|}{ Wearing denture } \\
\hline Yes & 47 & 43.1 & & \\
\hline No & 62 & 56.9 & & \\
\hline \multicolumn{5}{|l|}{$\begin{array}{l}\text { Difficulty in } \\
\text { chewing food }\end{array}$} \\
\hline Yes & 71 & 65.1 & & \\
\hline No & 38 & 34.9 & & \\
\hline
\end{tabular}

Next, Table 2 shows the nutritional status among elderly in the study. Findings reveal that elderly are at risk of malnutrition $(\mathrm{M}=10.15, \mathrm{SD}=2.289)$. This is in line with past studies on nutritional status among Malaysian population in which elderly are prone to have nutritional deficiencies and they are at risk of malnutrition (Churak et al., 2019; Norazman, Adznam \& Jamaluddin, 2020; Rosli et al., 2019). It is believed that increase in age, low level of/no formal education and low income cause lower socioeconomic status. With this, Shahar et al., (2019) supported that the prevalence of low socioeconomic among older adults in the rural area $(50.6 \%)$ was high as compared to those in the urban area $(49.4 \%)$. From data analysis, the level of BMI is imbalance in elderly residents with more than half were overweight/obese and some were underweight. Besides, many elderly residents are not wearing denture and they reported having difficulty in chewing food. Baumgarten et al., (2017) explain losing of teeth is associated with poor chewing ability and eating habit. This explain the contributing factors for risk of malnutrition among the elderly.

Table 2 Nutritional Status among Elderly $(n=109)$

\begin{tabular}{|l|c|c|}
\hline & Mean (M) & Standard Deviation (SD) \\
\hline Nutritional Status & 10.15 & 2.289 \\
\hline
\end{tabular}

In Table 3, the findings of the study show that there was a statistically significant association among age $(p=0.000)$, alcohol consumption $(p=0.018)$ with nutritional status at significant value of 0.05 . However, there was no significant correlation found for gender and smoking as $p>0.05$.

Table 3: Association Between Demographic Variables (Age, Gender, Smoking and Alcohol Consumption) and Nutritional Status among Elderly $(n=109$

\begin{tabular}{|l|c|}
\hline Variable & Sig (2 tails) \\
\hline Age & $0.000^{*}$ \\
\hline Gender & 0.057 \\
\hline Smoking & 0.367 \\
\hline Alcohol consumption & $0.018^{*}$ \\
\hline${ }^{*}<<0.05$ &
\end{tabular}

As human become aged, the digestive system will decrease in gastric acid secretion, leading to lower absorption of iron and vitamin B12. Decrease in sense of taste and smell may result in poor appetite and alteration in eating habits that consequently lead to nutritional deficiencies (Armaya et al., 2015). Besides, deterioration in sensory functions such as vision loss related to old age can cause difficulty in food preparation and cooking. In addition, elderly residents are having one or more chronic diseases and many of them are having difficulty in chewing. All these explain the possible reasons for the 
correlation between age and risk of malnutrition among the older population residing in long houses.

The findings of the study reveal a significant association between alcohol consumption and nutritional status. This is congruent with Damayanthi et al. (2018), Lin et al., (2017) and Poda et al., (2019). This could be explained that alcohol inhibits the metabolism and absorption of nutrients by reducing the secretion of important digestive enzymes from the pancreas when lining of the cells in the stomach and intestinal tract are damaged. As a result, smoking impedes the nutrient process and causes nutritional disorders (Marcel \& Schub, 2018).

There is no statistically significant association found between gender and nutritional status. This finding is supported by Patil \& Shindle (2018), but contrary to studies by Churak et al., (2019) and Lin et al. (2017). In their studies, females are more independent in term of financial status and they are able to prepare food on their own. In the current study, both male and female residents are equally in lower socioeconomic status. Therefore, gender difference is not the significant factor in malnutrition. Data analysed also shows that there is no association between smoking and nutritional status among elderly residing in longhouses. The finding of the study is contradicted with Lin et al., (2017) and Poda et al., (2019). The reason for the inconsistent findings may be due to the fact that a majority of the female respondents do not smoke.

\section{CONCLUSION}

In conclusion, elderly residing in longhouses at Kuching and Serian are at risk of malnutrition. The findings of the study reveal that age and alcohol consumption are significant factors influence on level of nutritional status in older adults. This study highlights the needs to address nutritional status among elderly in the Sarawak divisions. It is essential for the government and local authority in the public health sector to take further actions in improving elderly's nutritional status for their health and well-being.

\section{Conflict of Interests}

The authors declare that they have no conflict of interest.

\section{ACKNOWLEDGMENT}

This article is extracted from a research project [ID: BN1-2020 (PR-04)] approved by The IMU JointCommittee on Research and Ethics, International Medical University. The authors express genuine gratitude for their funding and support. Also, the authors would like to thank the elderly respondents who have participated in this study.

\section{REFERENCES}

Agree, E. M. (2018). Demography of aging and the family. In: Future Directions for the Demography of Aging Proceeding Workshop. Washington, DC: National Academies Press, 159-186.

Amarya, S., Singh, K., \& Sabharwal, M. (2015). Changes during aging and their association with malnutrition. Journal of Clinical Gerontology and Geriatrics, 6(3), 78-84.

Azhar, A., Rahman, M. M., \& Arif, M. A. (2016). Satisfaction on Primary Healthcare Services in Sarawak, Malaysia: Evidence from A Cross-Sectional Community Based Study. Malaysian Journal of Public Health Medicine, 16(3), 267-273.

Baumgarten, A., Schmidt, J. G., Rech, R. S., Hilgert, J. B., \& de Goulart, B. N. G. (2017). Dental status, oral prosthesis and chewing ability in an adult and elderly population in southern Brazil. Clinics, 72(11), 681-685.

Cheong, S. M., Jasvindar, K., Lim, K. H., Surthahar, A., \& Ambigga, D. (2017). Prevalence and factors influencing fruit and vegetable consumption among Malaysian elderly. International Journal of Public Health and Clinical Sciences, 4(1), 41-52.

Churak, P., Praditsorn, P., Meenongwah, J., \& Wimonpeerapattana, W. (2019). Factors associated with nutritional status of elderly in Ubon Ratchathani, Thailand. Asia-Pacific Journal of Science and Technology, 24(1), 1-12.

Damayanthi, H. D. W. T., Moy, F. M., Abdullah, K. L., \& Dharmaratne, S. D. (2018). Prevalence of malnutrition and 
associated factors among community-dwelling older persons in Sri Lanka: A cross-sectional study. $B M C$ Geriatrics, 18(1), 1-10.

Gomes, A. P., Soares, A. L., \& Gonçalves, H. (2016). Low diet quality in older adults: A population-based study in southern Brazil. Ciencia \& Saude Coletiva, 21(11), 3417-3428.

Lin, W. Q., Wang, H. H. X., Yuan, L. X., Li, B., Jing, M. J., Luo, J. L., Tang, J., Ye, B. K., \& Wang, P. X. (2017). The unhealthy lifestyle factors associated with an increased risk of poor nutrition among the elderly population in China. The Journal of Nutrition, Health \& Aging, 21(9), 943-953.

Mangels, A. R. (2018). Malnutrition in older adults. The American Journal of Nursing, 118(3), 34-41.

Marcel, C. B., \& Schub, T. B. (2018). Alcohol Use Disorder: Dietary Considerations. Retrieved from: https://eds-aebscohost-com.ezp2.imu.edu.my/eds/detail/detail?vid=4\&sid=44fa5c75-6559-447c-986f-

Ministry of Health (2019). Program Pembasmian Kemiskinan Bandar (PPKB). Retrieved from: https:// www.kpkt.gov.my/index.php/pages/view/285

Nohan, A. F., Adznam, S. N. A., Jamaluddin, R., \& Norazman, C. W. (2020). Diet Quality and its Associated Factors among Community Dwelling Older Adults in Urban District in Kuala Lumpur, Malaysia. Malaysian Journal of Medicine and Health Sciences, 16(6), 153-162.

Norazman, C. W., Adznam, S. N. A., \& Jamaluddin, R. (2020). Malnutrition as key predictor of physical frailty among Malaysian older adults. Nutrients, 12(6), 1-12.

Patil, D. J., \& Shindhe, M. M. (2018). Nutritional status assessment of elderly using MNA tool in Rural Belagavi: A cross sectional study. International Journal of Community Medicine and Public Health, 5(11), 4799-4803.

Poda, G. G., Hsu, C. Y., Rau, H. H., \& Chao, J. C. J. (2019). Impact of socio-demographic factors, lifestyle and health status on nutritional status among the elderly in Taiwan. Nutrition Research and Practice, 13(3), 222-229.

Rapacciuolo, A., Perrone Filardi, P., Cuomo, R., Mauriello, V., Quarto, M., Kisslinger, A., Savarese, G., Illario, M. \& Tramontano, D. (2016). The impact of social and cultural engagement and dieting on well-being and resilience in a group of residents in the metropolitan area of Naples. Journal of Aging Research, 2016.

Rosli, T. I., Chan, Y. M., Kadir, R. A., \& Hamid, T. A. A. (2019). Association between oral health-related quality of life and nutritional status among older adults in district of Kuala Pilah, Malaysia. BMC Public Health, 19(4), 547.

Shahar, S., Vanoh. D., Ludin, A. F. M., Singh, D. K.A., \& Hamid, T. A. (2019). Factors associated with poor socioeconomic status among Malaysian older adults: An analysis according to urban and rural settings. $B M C$ Public Health, 19(4).

Wong, M. M. H., So, W. K., Choi, K. C., Cheung, R., Chan, H. Y., Sit, J. W., Ho. B., Li., F., Lee. T. Y., \& Chair, S. Y. (2019). Malnutrition risks and their associated factors among home-living older Chinese adults in Hong Kong: Hidden problems in an affluent Chinese community. BMC Geriatrics, 19(138).

Zainal, Z. N., Iza Syazwina, M., Amirah Nuraisha, K., \& Sabariah, A. (2019). Prevalence of smoking and association with dietary practice among the community of apartments at Dengkil, Sepang, Selangor, Malaysia. International Journal of Education and Research, 7(3), 171-180. 